\title{
Erratum to: Primary and minor indications to bedside renal ultrasonography
}

\author{
Vincenzo Arienti • Valeria Camaggi
}

Published online: 20 June 2012

(C) SIMI 2012

Erratum to: Intern Emerg Med (2012) 7:89-90

DOI 10.1007/s11739-011-0711-7

Unfortunately, first and last name of authors (Vincenzo Arienti and Valeria Camaggi) has been interchanged in the original publication.

The authors name are corrected here.

The online version of the original article can be found under doi:10.1007/s11739-011-0711-7.

V. Arienti · V. Camaggi $(\bowtie)$

Department of Internal Medicine, Maggiore Hospital,

Largo B. Nigrisoli 2, 40133 Bologna, Italy

e-mail: v.camaggi@ausl.bologna.it 